ISSN: 2036-5438

\title{
The Second-Generation Theory of Fiscal Federalism: A Critical Evaluation
}

by

John Boye Ejobowah*

Perspectives on Federalism, Vol. 10, issue 1, 2018 


\section{Abstract}

This paper evaluates the second-generation theory (SGT) of fiscal federalism. It spells out the main arguments of the theory and discusses the fiscal architecture of Nigerian federalism with a view to using the case study to work out the strengths and weaknesses of the theory. After arguing that the weaknesses of the theory outweigh its strength, the paper goes on to point out the dangers of using a particular construct of fiscal federalism as a model. It notes that SGT theory is an attempt at reviving and modelling nineteenth century American fiscal federalism as a universal standard.

\section{Key-words}

first generation theory of fiscal federalism (FGT), second generation theory of fiscal federalism (SGT), transfer payments, bailouts, subnational governments, central governments soft budget constraint (SBC), hard budget constraint (HBC) 
Central government bailouts of regional governments, and equalisation transfers to economically distressed regions, have become major issues of our time, especially following the global financial crisis of 2007-2008. In the European Union (EU), the creation of the European Financial Stability Facility (later succeeded by the European Stability Mechanism) to assist member states in financial trouble was considered a breach of the Maastricht Treaty's no bailout clause, and was unsuccessfully litigated in the German constitutional court. In the United States, federal interventions during the Obama presidency were considered by some as the collapse of what was once the glory of American federalism, namely, 'a credible commitment against bailing out spendthrift junior governments' (Greve 2012: 18). In Nigeria, monthly federal transfers of oil revenues to the states since the early 1970s have been viewed by a section of the public to be the Achilles' heel of the country's federalism. In the intellectual community, there is the view that transfer payment programmes in Canada have not only kept impoverished areas even more depressed, but are also making the bigger and richer provinces like Ontario and Quebec dependent on the centre for their revenues (Eisen and Lamman 2017). A question to ask then, is whether central governments should provide transfer payments and bailouts to subnational governments? By transfer payments I mean financial transfers from the federal to the regional units of government done under a variety of programmes to tackle vertical and horizontal imbalances. A bailout means 'ad hoc additional funding that is provided' when a unit of government is in financial trouble (Rodden et al. 2003: 8; Watts 2001: 459).

There are two sets of literature that discuss the above question. One is the firstgeneration theory (FGT) of fiscal federalism that discussed functional and tax assignments between the orders of government. By FGT I refer to the normative fiscal federalism theory of the 1950,1960s, and early 1970s, which assumed that decision makers are benevolent actors who would intervene to provide public goods efficiently should the market fail to do so (Weingast 2014; Oates 2005; Inman and Rubinfeld 1997). According to the theory, central government is expected to provide national public goods that are deemed necessary, and take a leading role in macroeconomic stabilisation policy and in designing measures for income redistribution. Intergovernmental transfer payments and grants necessary for correcting vertical and horizontal imbalances are inherent in the interventionist roles of the federal order. This vision of FGT has been questioned by 
another body of scholarship, generally referred to as the second-generation theory (SGT) of fiscal federalism. Unlike the earlier theory, SGT does not assume that public officials are benevolent actors who seek to maximise public interest (Weingast 2014). Instead, it regards actors as having divergent goals. SGT, therefore, pays attention to the institutional incentives that induce or constrain the behaviour of officials as they interact within and across the tiers of government. One of its central claims is that intergovernmental transfers and bailouts encourage sub-national governments to spend freely and to offload the cost of their profligacy on the central government - actions which undermine macroeconomic stability. Consequently, SGT prescribes minimal intergovernmental transfers and a nobailout policy. In this paper, I evaluate the arguments of SGT in order to establish that:

a) there is merit in the claim that intergovernmental transfers and bailouts foster a culture of over spending;

b) the prescriptions of SGT, while reasonable in some respects, are fundamentally at odds with the peculiarities of a multinational federation founded on a fiscal regime of intergovernmental transfers; and,

c) SGT theory is an attempt at reviving nineteenth century American fiscal federalism, and modelling it as a universal standard.

I develop the above arguments by drawing on Nigerian fiscal federalism. There are good reasons for using Nigeria as a case study. Africa's oldest federation has a fiscal arrangement that is defined by intergovernmental transfer payments, which SGT considers to be soft budget constraints that breed sub-national fiscal indiscipline and prop up otherwise insolvent governments (Wildasin 1997; Rosas 2006). Secondly, Nigeria experienced sharp declines in export revenues when oil prices collapsed in 2015. The decline significantly reduced monthly intergovernmental transfer payments, and threatened the functioning of state governments, plunging the country into a painful economic recession, and compelling the centre to provide three consecutive bailouts in 2015, 2016, and 2017. Thirdly, Nigeria's public discourse is riven by clamours for what a wide spectrum of local actors refers to as "true federalism". Central to this call is the devolution of fiscal autonomy to the component states of the federation. The clamour for "true federalism" reflect the arguments of SGT for an ideal fiscal arrangement in which sub-national governments have autonomous taxing powers and each takes care of its own fiscal 
situation, without relying on intergovernmental transfers or bailouts. In this paper I intend to refute the notion that there is an ideal fiscal model for all federations to follow.

The paper will proceed by firstly briefly defining SGT's normative arguments of fiscal federalism. The second section will discuss the fiscal architecture of Nigerian fiscal federalism (defined by central pooling and sharing of revenues) and the problems it generates. Next, the paper will use the data of the case study to highlight the strengths and weaknesses of SGT. The fourth section will discuss the dangers of generalising a particular model of fiscal federalism, showing that the theory is derived from $19^{\text {th }}$ century American fiscal federalism that has since collapsed. The paper ends with a conclusion.

\section{Second-Generation Theory and Federal Bailouts}

Contemporary theories of federal bailouts have their roots in FGT. They could best be regarded as a reaction to the latter's prescriptions regarding the assignment of functional and taxing powers to the orders of government and the resulting vertical imbalances.

In brief, FGT argued that, for reason of efficiency, higher tier governments should provide goods that are non-congestible, meaning those goods that a non-paying individual cannot be prevented from enjoying -- e.g. national defence. Also for reason of efficiency, lower tier governments should have responsibilities over those goods that benefit local consumers, and which residents of their respective jurisdictions prefer, given that the tastes for goods are local-specific, and local authorities may have more accurate information about what the locals want (Tiebout 1961). In cases where the provision of local goods generates externalities, the centre handles the issue by providing subsidies or grants to internalise the benefits (Oates 1972). In respect of what was known as the 'tax assignment problem' (McLure 2001: 339) i.e. which level of government should get what taxing powers, the literature noted that lower order governments would perform their functions in an open economy in which they have no control over prices and employment levels. In this model, low income house-holds would migrate into efficiently run jurisdictions while better-off residents out-migrate. Hence, the theory suggested that income redistribution be assigned to the first order of government. Thus, corporate income taxes and progressive personal income taxes, the main instruments for income redistribution, are assigned to the 
federal level while taxes that have little or no consequence for macroeconomic stability (e.g. sales tax and property tax) are assigned to sub-national governments (Musgrave 1959).

Further, FGT was concerned that horizontal jurisdictional differences in the taxation of mobile economic units would make for inefficiencies because the taxed units would relocate to areas with favourable tax jurisdictions. To head off the inefficiencies, the literature suggested that sub-national governments should avoid taxes that do not benefit mobile units; instead they should rely on benefit taxes while the centre should exercise authority over non-benefit taxes. Where there are significant regional economic disparities, the centre would provide equalisation payments to the have-not-jurisdictions so individuals in similar positions would have similar fiscal treatment regardless of their jurisdiction (Mieszkowski and Musgrave 1999; Oates 2004; Buchanan 1950). On the whole, FGT prescribed functional and tax assignments between orders of government on the grounds of efficiency and macroeconomic stability. In cases of vertical fiscal imbalance and of horizontal economic disparities, the centre was required to make transfer payments.

Prescriptions for transfer payments have come under intense questioning by SGT. While accepting the basic premise of FGT regarding the appropriate assignment of functional responsibilities, SGT charts a new direction by emphasising subnational governments' reliance on own resources for their functioning. It argues that horizontal competition between subnational governments can make for economic efficiency and prosperity, if the federal level refrains from interfering in these government's taxing and spending decisions. It regards federal fiscal interventions (equalisation payments, grants, bailouts, etc.) as distortionary policy instruments that inhibit the development of a competitive and efficient economy. The interventions are termed 'soft budget constraints' (SBC), which induce subnational governments to spend excessively, amass unsustainable deficits, and to perpetuate their dependence on the centre for more support (McKinnon and Nechyba 1997). Kornai (1980; 1986) explained the concept of 'soft budget constraint' (SBC) to mean the practice whereby public enterprises perpetually posted losses and were always bailed out with state funds. Such enterprises operating at chronic losses could count on external assistance, an expectation that defined the behaviour of their top management. The concept is applied to subnational governments (Kornai, Maskin \& Roland 2003).

SGT emphasises the dangers of SBC in federal political systems. It claims that federal transfer payments are weak incentives for subnational governments to pay attention to 
their size, and make prudent fiscal decisions of either saving during good times, or refraining from borrowings that are assumed to be guaranteed by the centre. It is also claimed that the willingness of the centre to bailout subnational governments is an incentive for the latter to opportunistically shift their overspending cost and excessive borrowings to other jurisdictions - the so called common pool problem (Burret and Feld 2014; Oates 2005; Rodden and Wibbels 2002). Thus, SBC creates a moral hazard: the centre acts like a financial insurer which encourages the insured to continuously engage in the same fiscally reckless behaviour. This opportunistic fiscal behaviour is said to have facilitated the Argentine and Brazilian fiscal crises of the 1980s and 1990s as well as the post-2008 debt crises of the weak member states of the European Union (Rodden 2012). Given these problems, the literature prescribes hard budget constraint (HBC) for subnational governments.

The concept of hard budget constraint (HBC) refers to a situation in which entities cover their expenditures from their own revenues and if deficits arise cannot count on external support (Kornai, Maskin \& Roland 2003). SGT prescribes market-based and rulebased institutional mechanisms that would create HBC (Ter-Minassian 1997). Marketbased institutional mechanisms involve the establishment of an efficient market in combination with a decentralised system in which subnational governments have autonomous taxing and expenditure powers. In this setting, subnational governments could borrow from the credit market but creditors would rate their fiscal performance and reduce credit access if performance is poor. Within this efficient market setting, excessive subnational government borrowing would manifest itself in depreciated property values that could prompt residents to migrate to fiscally sound jurisdictions (Rodden 2012). In contrast, rule-based institutional mechanisms are laws that prohibit deficits, severely limit borrowings, provide for credible no-bailout and minimal inter-governmental transfers, and allow for bankruptcy (Burret and Feld 2014; McKinnon and Nechyba 1997; Oates 2005; Skeel 2001; Ter-Minassian 1997).

This HBC vision has been touted as a force for economic growth and prosperity. For example, McKinnon and Nechyba (1997: 46) emphasised the combination of HBC and the taxing authority of constituent governments as the main force for turning much of the formerly poor southern U.S. states into the 'prosperous Sunbelt.' Similarly, Barry Weingast (1995) regarded a decentralised system, in which lower order governments make hard 
choices about their economic sustainability and the centre refrains from interfering in their affairs, as the source of prosperity not just in the United States but also in China. I examine the merits and demerits of these theoretical claims, and I begin by laying out the practical Nigerian experience with federal transfer payments.

\section{The Fiscal Architecture of Nigerian Federalism}

Nigerian fiscal architecture is characterised by legally mandated federal levying and collection of broad-based revenue. This fiscal arrangement assigns major revenue sources to the federal government, while subnational governments are left with inconsequential taxation jurisdictions. ${ }^{\text {I }}$ The taxation arrangement creates vertical imbalance, as the states own generated revenues do not match their constitutional responsibilities. Hence, in Nigeria's fiscal architecture, subnational governments rely on tax revenues raised by the centre.

However, the major tax revenues generated by the centre belong to the entire federation and the constitution requires that they be lodged in a common account, the Federation Account (FA), in the Central Bank for vertical and horizontal sharing among the orders of government. Oil is the most dominant of the tax revenues, consistently accounting for at least $70 \%$ of consolidated revenue and $90 \%$ of export earnings. Its contribution to GDP has been falling over the years, from $29.92 \%$ in 2009 to $15.78 \%$ in $2012,10.80 \%$ in 2014 , and $6.36 \%$ in $2015{ }^{\text {II }}$ Comparatively, corporate and value added taxes (VAT), the next most important revenue sources, respectively accounted for $12 \%$ and 7.9\% of total revenues in 2014 and 2015 (CBN 2015:310; CBN 2014a: 259; CBN 2013: 365; OPEC 2015). ${ }^{\text {III }}$ The FA is, therefore, dominated by revenues from oil and gas and is shared by first removing $13 \%$ share of derivation for the oil producing states. The remainder is distributed vertically at the ratio of $52.68 \%$ Federal, $26.72 \%$ State, and $20.60 \%$ Local Government. ${ }^{\text {IV }}$

The central collection and sharing of revenues is not uncommon in federations: it is the practise in the Argentine, Mexican, Indian, and Russian federations. But Nigeria's architecture is distinctive for pooling all the major revenues in a common basket in the Central Bank from which all the governments are legally entitled to share without any condition attached. In 2013 the common pool supplied $81.2 \%$ and $92 \%$ of the total annual 
revenues of the states and federal governments respectively (CBN 2014a: 126; 2013: 163). The figures were $72.2 \%$ for the states and $72.5 \%$ for the federal level in 2015 (CBN 2015:146 \& 153; 2013:158). The state governments have absolute autonomy to spend the funds they receive without any compliance with federal initiatives.

The dependence on a common pool of resources produces incentives for the states to misalign their expenditures with their revenues. Theoretically, subnational governments' autonomy to determine their own public spending is sometimes taken as a measure of the level of fiscal decentralisation and therefore an enhancer of federalism. However, a regime of fiscal commons and expenditure autonomy are a deadly combination. Nigerian state governments spend freely, on the expectation that the Central Bank will automatically funnel funds from the common pool. Indeed, after the country transited from military to democratic rule (1999-2000), the price of oil began an upward tick (from $\$ 30$ per barrel in 1999 to a peak of $\$ 152$ in 2008) and the states began to escalate their budgets in line with transfers from the FA. Between 2001 and 2005, the states ran average annual deficits of 5\% of their total revenues. According to the World Bank (2007: 5), some states increased their budgets 'faster' than their proceeds from the FA, 'through domestic borrowing'. The passage of the Fiscal Responsibility Act (FRA) of 2007 was aimed at slowing the automatic pass-through of oil revenues to state spending.

The FRA established the Commodity Reference Price for oil, meaning budgeted national revenue for each year would be based on a predetermined low price of oil. The difference between the actual market price and the low budgeted benchmark would be saved in a holding account, the Stabilisation Account (SA), in the Central Bank. The FRA specified limits on the federal government's deficit-GDP ratio at no more than $3 \%$ and required the President, on the approval of the National Assembly, to set limits on the consolidated debt of the federal and state governments. Furthermore, state governments can only obtain external loans through the federal government if their debt servicing does not exceed 40 per cent of their average monthly statutory allocations from the FA. The law authorised the federal government to deduct funds monthly and upfront from a debtor state's gross statutory allocations, with a view to servicing the state government's external loans. And, domestic borrowing by any state had to be authorised by law passed by the state legislature, with the proceeds strictly restricted to long term capital expenditure. Since the FRA could not be imposed on state governments, the latter were incentivised to adopt 
their own fiscal responsibility laws in line with the 2007 Act. The incentives were financial and technical assistance from the federal government (Federal Republic of Nigeria 2007).

The FRA registered temporary gains. The use of the CRP in annual appropriations helped to slow the automatic pass-through of oil revenues for state spending. Oil proceeds were directed into the Stabilisation Account (SA, also referred to as the ECA) annually, the amount varying widely from year to year (Table 1). In addition, over twenty states enacted their own fiscal responsibility laws, and five established their own rainy-day reserve fund with the oil-rich Rivers State accumulating $\$ 343.7$ million by 2014 . The gains did not last.

The Problem of a Common Pool of Revenue: In a context where the operations of all tiers of government are dependent on a common pool of revenue, there is no incentive to adhere to prudent fiscal rules that are personally disadvantageous. With the centre serving as a financial insurance company to the state governments, the latter constantly engaged in the same pattern of destructive fiscal conduct. According to an old government report, Nigerians regard allocations from the fiscal common as 'booty-sharing' (Fed. Rep. of Nig. 1976: 10). A more recent study has shown that in contemporary Nigeria it is disadvantageous for an official to be self-restrained or to invest in the public good when everyone else is raiding the commons (Olowu and Wunsch 2014). Over four decades since Peter Ekeh (1975: 100) developed the idea of the public realm as an 'amoral civic public from which one seeks to gain', state resources are still regarded as the spoils of war available for taking and one is considered a "sucker" for not "eating" up the state. Indeed, the concept of "eating" in African political discourse aptly expresses the opportunistic act of helping oneself to the resources of state and the irrelevance of laid down formal rules (Berman 2004). This common pool problem constrains Nigerian state officials from committing to the fiscal responsibility laws they enacted.

For example, the majority of states that enacted fiscal responsibility laws did not establish the commissions required to implement and enforce these; this made the enacted laws redundant. Also, state governments that established reserve funds quickly depleted them even before oil prices began to decline. Furthermore, the ECA, that was supposed to serve as a rainy-day fund, was regularly drawn-down (Table 1) partly at the request of the thirty-six state governors who also litigated in the country's courts whenever the Federal Government refused to accede to their requests. As a consequence of their spending, state governments posted average annual deficits of 4.7\% from 2006 to 2013 (Table 2). These 
persistent deficits were consistently financed through domestic banks at high interest rates of $20 \%$ and above. Worse still, debtor states provided Irrevocable Standing Payment Orders (sort of pre-authorised automatic debit) authorising the Central Bank to deduct their monthly allocations upfront on behalf of the creditor banks.

Table 1: Excess Crude Account Annual Proceeds \& Withdrawals 2009-2015

\begin{tabular}{|l|c|c|c|c|}
\hline \multirow{2}{*}{ Year } & \multicolumn{2}{|c|}{$\begin{array}{c}\text { Non-Cumulative } \\
\text { Proceeds }\end{array}$} & \multicolumn{2}{c|}{$\begin{array}{c}\text { Non-Cumulative } \\
\text { Withdrawals }\end{array}$} \\
\cline { 2 - 5 } & $\begin{array}{c}\text { Naira } \\
\text { (billion) }\end{array}$ & $\begin{array}{c}\text { Dollar } \\
\text { Equivalent } \\
\text { (billion) }\end{array}$ & $\begin{array}{c}\text { Naira } \\
\text { (billion) }\end{array}$ & $\begin{array}{c}\text { Dollar } \\
\text { Equivalent } \\
\text { (billion) }\end{array}$ \\
\hline $\mathbf{2 0 0 9}$ & 60.4 & 0.41 & 812.4 & 5.43 \\
\hline $\mathbf{2 0 1 0}$ & 615.8 & 4.81 & 886.5 & 5.88 \\
\hline $\mathbf{2 0 1 1}$ & $1,226.2$ & 8.04 & 450.0 & 2.95 \\
\hline $\mathbf{2 0 1 2}$ & $2,420.0$ & 15.50 & 387.7 & 2.48 \\
\hline $\mathbf{2 0 1 3}$ & 50.6 & 0.32 & 464.2 & 2.98 \\
\hline $\mathbf{2 0 1 4}$ & 216.0 & 1.37 & 76.0 & 0.48 \\
\hline $\mathbf{2 0 1 5}$ & 12.6 & 0.06 & 15.6 & 0.08 \\
\hline
\end{tabular}

Source: National Bureau of Statistics (2012); CBN (2015: 287 \& 288; 2013);

*Exchange rate (N/\$) of 147.27 (2009); 148.51(2010); 152.59 (2011); 156.23 (2012); 156.03 (2013); 157.27 (2014); 196.49 (2015)

By the end of 2015, the 36 states and the Federal Capital Territory (FCT) owed $\$ 12.7$ billion in domestic debt and another $\$ 3.4$ billion in external debt. These were heavy debts when considered in terms of total revenues received. For example, the total domestic debt of the states and the FCT averaged 91 percent of their total revenues (Table 3). This did not include their external debts. The picture worsens when transfer payments are taken out of the picture, as the states generated an average of $19 \%$ of their revenues internally in 2015, upward from $15.3 \%$ in 2013. 
Table 2: Summary of State Governments' and Federal Capital Territory Finances (Naira Billion)

\begin{tabular}{|c|c|c|c|c|c|c|c|c|c|}
\hline Fiscal Indicator & $\mathbf{2 0 0 6}$ & $\mathbf{2 0 0 7}$ & $\mathbf{2 0 0 8}$ & $\mathbf{2 0 0 9}$ & $\mathbf{2 0 1 0}$ & $\mathbf{2 0 1 1}$ & $\mathbf{2 0 1 2}$ & $\mathbf{2 0 1 3}$ & $\mathbf{2 0 1 4}$ \\
\hline $\begin{array}{c}\text { Total Revenue } \\
\text { (TR) }\end{array}$ & $\mathbf{1 , 5 4 3 . 8}$ & $\mathbf{2 , 0 6 5 . 4}$ & $\mathbf{2 , 9 3 4 . 8}$ & $\mathbf{2 , 5 9 0 . 7}$ & $\mathbf{3 , 1 6 2 . 5}$ & $\mathbf{3 , 4 1 0 . 1}$ & $\mathbf{3 , 5 7 2 . 6}$ & $\mathbf{3 , 9 0 5 . 4}$ & $\mathbf{3 , 6 7 2 . 0}$ \\
& & & & & & & & & \\
\hline Total Expenditure & $\mathbf{1 , 5 8 6 . 8}$ & $\mathbf{2 , 1 1 6 . 1}$ & $\mathbf{3 , 0 2 1 . 6}$ & $\mathbf{2 , 7 7 6 . 9}$ & $\mathbf{3 , 2 6 6 . 2}$ & $\mathbf{3 , 5 4 2 . 0}$ & $\mathbf{3 , 8 4 5 . 1}$ & $\mathbf{4 , 0 4 6 . 8}$ & $\mathbf{3 , 9 8 3 . 0}$ \\
& & & & & & & & & \\
Rec. Exp. & 894.3 & $1,217.4$ & $1,505.6$ & $1,426.1$ & $1,648.4$ & $2,055.8$ & $1,664.4$ & $1,948.4$ & $2,120.5$ \\
Rec. Exp./TR \% & $57.9 \%$ & $58.9 \%$ & $51.3 \%$ & $55.0 \%$ & $52.1 \%$ & $60.2 \%$ & $46.6 \%$ & $49.9 \%$ & $57.7 \%$ \\
Capital Exp. & 584.0 & 854.8 & $1,455.7$ & $1,284.2$ & $1,522.4$ & $1,375.2$ & $1,965.3$ & $1,890.4$ & $1,862.5$ \\
Ext.-Budget Exp. & 108.5 & 43.9 & 60.3 & 66.7 & 95.4 & 111.0 & $\mathbf{2 1 5 . 4}$ & 207.97 & 0.00 \\
\hline Overall Balance & -43.0 & -50.7 & -86.8 & -186.2 & -103.7 & -131.9 & -272.5 & -141.42 & -310 \\
& & & & & & & & & \\
Financing & & & & & & & & & \\
Ext. Loans & 00.00 & 00.00 & 00.00 & 8.00 & 7.6 & 41.3 & 10.4 & 31.48 & 24.35 \\
Int. Loans & 27.0 & 25.7 & 60.2 & 162.3 & 88.1 & 170.4 & 223.4 & 412.37 & 261.9 \\
Other Funds & 16.1 & 19.1 & -11.69 & 16.0 & 8.0 & -79.8 & 38.7 & -302.43 & 24.68 \\
\hline $\begin{array}{c}\text { Deficit as \% of } \\
\text { Total Revenue }\end{array}$ & $\mathbf{2 . 7 9}$ & $\mathbf{2 . 4 5}$ & $\mathbf{2 . 9 6}$ & 7.19 & 3.28 & 3.86 & 7.62 & 3.62 & $\mathbf{8 . 4 4}$ \\
\hline $\begin{array}{l}\text { Average Crude } \\
\text { Oil Price (US\$/b) }\end{array}$ & $\mathbf{6 6 . 4}$ & $\mathbf{7 4 . 9 6}$ & $\mathbf{1 0 1 . 2}$ & $\mathbf{6 2 . 1}$ & $\mathbf{8 0 . 8}$ & $\mathbf{1 1 3 . 8}$ & $\mathbf{1 1 3 . 5}$ & $\mathbf{1 1 1 . 3 6}$ & $\mathbf{1 0 0 . 7 4}$ \\
\hline
\end{tabular}

Source: CBN 2014b; 2013; 2009. 
Table 3: State Governments' and Federal Capital Territory's Finances (2015)

\begin{tabular}{|c|c|c|c|c|c|c|c|}
\hline STATE & $\begin{array}{c}\text { Domestic } \\
\text { Debt } \\
\text { (NGN million) } \\
\star\end{array}$ & $\begin{array}{c}\text { External } \\
\text { Debt }\end{array}$ & $\begin{array}{c}\text { IGR } \\
\text { (NGN billion) } \\
* \\
\end{array}$ & $\begin{array}{c}\text { Total } \\
\text { Revenue }\end{array}$ & $\begin{array}{c}\text { IGR } \\
\text { Total } \\
\text { Revenue } \\
(\%) \\
\end{array}$ & $\begin{array}{c}\text { Domestic } \\
\text { Debt } \\
\text { IGR }(\%)\end{array}$ & $\begin{array}{c}\text { Domestic } \\
\text { Debt } \\
\text { Total Revenue } \\
(\%)\end{array}$ \\
\hline & & (US\$ million) & & (NGN billion) * & & & \\
\hline $\mathrm{ABIA}$ & 33.53 & 41.5 & 20 & 62.2 & 32.2 & 167.7 & 53.9 \\
\hline ADAMAWA & 47.2 & 49.1 & 4.5 & 44.7 & 10.1 & 1048.9 & 105.6 \\
\hline AKWA IBOM & 147.58 & 52.7 & 11.1 & 178.3 & 6.2 & 1329.5 & 82.8 \\
\hline ANAMBRA & 3.58 & 60.8 & 9.4 & 50.4 & 18.7 & 38.1 & 7.1 \\
\hline $\mathrm{BAUCHI}$ & 57.65 & 85.3 & 6.3 & 74.7 & 8.4 & 915.1 & 77.2 \\
\hline BAYELSA & 103.37 & 37.6 & 9.3 & 118.9 & 7.8 & 1111.5 & 87 \\
\hline BENUE & 39.94 & 35.7 & 6.2 & 61.1 & 10.1 & 644.2 & 65.4 \\
\hline BORNO & 22.34 & 23.2 & 2.3 & 51 & 4.5 & 971.3 & 43.8 \\
\hline CROSS-RIVER & 115.52 & 136.4 & 11.8 & 52.1 & 22.6 & 979 & 221.7 \\
\hline DELTA & 320.61 & 38.8 & 34 & 175.1 & 19.4 & 943 & 183.1 \\
\hline EBONYI & 34.17 & 47.2 & 7.6 & 43.6 & 17.4 & 450 & 78.4 \\
\hline EDO & 46.29 & 168.2 & 18.1 & 68.3 & 26.5 & 255.7 & 67.8 \\
\hline EKITI & 52.57 & 55 & 7.8 & 46.5 & 16.8 & 674 & 113.1 \\
\hline ENUGU & 37.55 & 71.8 & 50.1 & 94.3 & 53.1 & 75 & 39.8 \\
\hline GOMBE & 53.45 & 39.8 & 3.5 & 41.9 & 8.4 & 1527.1 & 127.6 \\
\hline $\mathrm{IMO}$ & 71.74 & 59.2 & 5.4 & 51.6 & 10.5 & 1328.5 & 139 \\
\hline JIGAWA & 22.2 & 34.1 & 2.9 & 53.6 & 5.4 & 765.5 & 41.4 \\
\hline KADUNA & 49.85 & 226.4 & 13.6 & 66.3 & 20.5 & 366.5 & 75.2 \\
\hline KANO & 65.01 & 57.6 & 31.1 & 96.8 & 32.1 & 209 & 67.1 \\
\hline KATSINA & 11.5 & 72.2 & 4.3 & 54.3 & 7.9 & 267.4 & 21.2 \\
\hline KEBBI & 63.79 & 45.3 & 3.6 & 49.8 & 7.2 & 1772 & 128.1 \\
\hline KOGI & 42.04 & 33.6 & 3.7 & 47.2 & 7.8 & 1136.2 & 89.1 \\
\hline KWARA & 31.97 & 51 & 4.2 & 40.4 & 10.4 & 761.2 & 79.1 \\
\hline LAGOS & 218.54 & 1208 & 253.5 & 369.4 & 68.6 & 86.2 & 59.2 \\
\hline NASSARAWA & 40.56 & 53.1 & 5.9 & 42.4 & 13.9 & 687.5 & 95.7 \\
\hline NIGER & 21.5 & 44.8 & 4.3 & 51.1 & 8.4 & 500 & 42.1 \\
\hline OGUN & 75.92 & 103.3 & 39 & 77.8 & 50.1 & 194.7 & 97.6 \\
\hline ONDO & 26.65 & 52.1 & 10.2 & 64.4 & 15.8 & 261.3 & 41.4 \\
\hline OSUN & 144.7 & 76.9 & 7.7 & 45.4 & 17 & 1879.2 & 318.7 \\
\hline OYO & 47.44 & 66.6 & 21.5 & 69.5 & 31 & 220.7 & 68.3 \\
\hline PLATEAU & 96.21 & 30.5 & 2.6 & 44.4 & 5.9 & 3700.4 & 216.7 \\
\hline RIVERS & 134.97 & 46.9 & 94.5 & 216.9 & 43.6 & 142.8 & 62.2 \\
\hline SOKOTO & 11.66 & 41.9 & 13.7 & 59.8 & 22.9 & 85.1 & 19.5 \\
\hline TARABA & 27.65 & 22.9 & 15.8 & 54.3 & 29.1 & 175 & 50.9 \\
\hline YOBE & 3.87 & 30.5 & 1.8 & 41.1 & 4.4 & 215 & 9.4 \\
\hline ZAMFARA & 46.28 & 34.9 & 3.1 & 43.3 & 7.2 & 1492.9 & 106.9 \\
\hline FCT & 133.9 & 35 & 11.5 & 66.2 & 17.4 & 1164.3 & 202.3 \\
\hline Total & 2503.26 & 3370 & 755.9 & 2859 & 18.9 & 771.4 & 90.5 \\
\hline
\end{tabular}

Source: Debt Management Office (2015); CBN (2015)

*Provisional data

Without transfers from the common pool, the majority of states would be classified as heavily indebted. As Table 3 shows, the 2015 average domestic debt of the 36 states and the FCT was $771.4 \%$ of their internally generated revenue (IGR), well in excess of the World Bank's debt sustainability threshold of 200 percent of IGR. No fewer than twentynine states have domestic debt-IGR ratio several times above the World Bank's sustainability ceiling. These include both the oil producing states and the agrarian states in 
the North and South. Oil-rich Akwa Ibom State has a domestic debt burden that is over thirteen times its domestic earnings, while the agrarian Plateau State in the middle belt owes over thirty-seven times its local revenue. This heavy debt burden does not include what the states owe to external creditors.

Given the states' unsustainable debt and lack of an independent revenue base, any significant decline in monthly federal transfer payments would impact negatively on their operations. Declines in transfer payment could truly cripple state governments, as recurrent expenditures consume over half of their revenues. As Table 2 shows, in 2014 recurrent expenditure accounted for $57.7 \%$ of the total revenue of the 36 states. Over a period of nine years (2006-2014), the average annual recurrent spending was $54.4 \%$ of total revenue. Declines in federal transfers could potentially translate into an inability of the states to meet their recurrent bills. That potential became a reality when the global price of oil fell precipitously in 2015. The Federal Government provided $\$ 2.1$ billion of bailout loans to enable 27 insolvent states pay their recurrent expenditure bills, in apparent violation of its FRA that specifically limited the application of loans to capital expenditure only. Much of the funds were reported by the country's anticorruption commission to have been either mismanaged or diverted by the governors in most of the recipient states (Independent Corrupt Practices and other Related Offences Commission 2016). The apparent insolvency did not go away, and by April of 2016 several states could not carry out their basic functions of government. ${ }^{\mathrm{V}}$ Again the Federal Government provided relief by suspending its deductions of debt servicing costs from each debtor state's monthly share of federal transfer payments. It further provided $\$ 324.4$ million (NGN90 billion) for the states to meet their recurrent expenditure commitments, even though the previous bailout had been wasted by most of the governors, and regardless of the FRA restriction of loan usage to capital expenditure only. However, accessing the funds was made conditional on the production of a fiscal sustainability plan. The content of the required plan was similar to some aspects of the earlier mentioned rule-based HBC recommended by the SGTFF, but did not include a no-bailout policy or the possibility of states' bankruptcy.

\section{The Implications of the Nigeria Experience for SGT}


The above case study data has implications for SGT as it helps to shed light on the strengths and weaknesses of the theory.

The Strength of the Theory: The primary claim of SGT is that transfer payments create a moral hazard as these are an incentive for subnational governments to continuously overfish the common pool of revenue. The Nigerian experience validates this claim. Nigeria's state governments expand their expenditures by building heavy personnel and overhead obligations, operating persistent deficits, borrowing perennially from local banks and then calling regularly on the centre to divide up reserve funds in the ECA to cover these costs. Between 2009 and 2014, a total of $\$ 20.2$ billion was taken out of the rainy-day fund (see Table 1). The draw-down occurred at a time when other oil producing countries were building up their reserves (World Bank 2013). According to the Central Bank, by the end of 2015 only $\$ 2.45$ billion was left in the ECA (CBN 2015: 137). Former President Goodluck Jonathan (2016) has noted that he was pressured by the state governors to withdraw and share the funds. This was a clear case of overfishing the common pool. Over fishing is logical, given the fiscal arrangement in which the centre has taxation autonomy while the states have expenditure powers. Left to themselves, the states would not reduce their expenditures because public officials (elected and unelected), and residents, regard the states as the primary means of capturing their 'shares of the federal cake' (Olowu and Wunsch 2014; Fed. Rep. of Nig. 1976): 10). It would be difficult to move against decades old vested interests of both public officials and citizens. Reducing expenditure would also be politically costly because the size of government would have to be trimmed, potentially pitching elected officials (who have the objective need to win voters' support) against the organised labour unions. The political consequences of crossing organised unions might constrain the officials from making fiscally prudent decisions that are unpalatable in the short run.

SGT prescribes HBCs as a solution to the above problem. The most pertinent HBCs are the rule-based mechanisms that prohibit deficits, limit borrowings, provide for nobailout, minimal intergovernmental transfers, and allow states to go bankrupt. According to the theory, a regime of intergovernmental transfers invites and perpetuates a culture of fiscal dependence on the part of the subnational governments. The Nigerian experience seems to, but does not prove this argument. The country's fiscal arrangement is a sort of division of labour: the centre raises and supplies the revenue while the subnational tier does 
the spending. Consequently, state governments do not have to engage themselves in the challenging task of sourcing local revenues. Indeed, following successive political restructurings of Nigeria from a regional to multi-state federation, there has been no deliberate and concerted effort by the states to expand their revenue base. Nigerian policy makers have, therefore, recognised the need to provide state governments with incentives to generate their own revenues. Hence, during the failed Second Republic (1979-1983), independent revenue generation was built into a formula for the horizontal sharing of funds from the FA (Phillips 1991). Yet, there has been no remarkable improvement. Throughout the 1970s transfers from the common pool accounted for $70-90 \%$ of the total revenues of the states (Phillips 1991). Four decades on, the figures remain the same. As table 3 shows, only Lagos State generated over two-thirds of its revenue in 2015, largely due to its position as a financial and commercial city state. This city-state also generates $55 \%$ of Nigeria's VAT. The next best states were Enugu, Ogun, and Rivers which generated $53.1 \%, 50.1 \%$ and $43.6 \%$ of their revenues, respectively. The agrarian Jigawa State generated 5.4\%, while the oil producing Akwa Ibom State generated 6.2\%.

The states could intensify their revenue generation efforts to reduce their dependence on transfer payments, but only a very few have the industrial and commercial economic base to achieve such autonomy. For most of the states that are agrarian, with smallholder farmers a majority of their residents, not much can be generated through taxation. It would be futile to expect that taxing subsistence farmers would produce the desired result. Heavy taxation could even be counterproductive as the development literature of 1980s and 1990s has since established that the African economic stagnation of the last three decades of the $20^{\text {th }}$ century was on account of fiscal policies that overtaxed the agricultural sector and squeezed out farmers (World Bank 1994; Schiff 1992). The agrarian economic orientation of majority of Nigerian states makes it difficult to suggest minimising federal transfer programmes or the prohibition of bailouts.

From the above it would be safe to state that there is merit in SGT's claim that intergovernmental transfers and bailouts create a moral hazards problem, but minimising intergovernmental transfers or prohibiting bailout is not feasible and might not be desirable as I detail below.

The Weaknesses of the Theory: The Nigerian experience also helps to understand the problems with SGT. First, the theory views subnational governments as being fiscally 
profligate and of the centre as being the victims of manipulation. But the Nigerian experience shows that the centre is no less guilty. The federal government's recurrent expenditure is $71 \%$ of its total spending and the upper tier accounted for $80.13 \%$ of the $\$ 57.4$ billion total debt owed to external and local creditors in 2016. Its deficits are modest (see Table 5), and differ little from those of the European Union; however, they are perennial, prompting the need for foreign loans to fund the country's annual budget. In 2017 the deficit was $2.2 \%$ of GDP and was financed through foreign loans. The centre is not as clean as the theory assumes.

\section{Table 4: Federal Government Fiscal Deficit,}

\section{9-2015 (\% of GDP)}

\begin{tabular}{|l|l|}
\hline Year & Deficit \\
\hline 2009 & -3.2 \\
\hline 2010 & -2 \\
\hline 2011 & -1.8 \\
\hline 2012 & -1.3 \\
\hline 2013 & -1.4 \\
\hline 2014 & -0.9 \\
\hline 2015 & -1.6 \\
\hline
\end{tabular}

Source: CBN (2015; 2013)

Secondly, Nigerian multistate federalism was created with the clear understanding that central redistribution of oil revenues would be the primary means of sustaining the component governments. At the time of independence in 1960, the federation was triregional, with each of the regions having extensive taxing and spending autonomies. The progressive restructuring of the federation from three regions (four in 1963) to thirty-six by 1996 was strictly for the political reasons of 'assuaging the fears of minorities', balancing the size of the constituent units, and guaranteeing 'political stability' (Federal Republic of Nigeria 1976: 10). Nigerian policy makers and the multistate federal engineers explicitly dismissed as 'irrelevant' expert advice that the component states would not be economically viable; instead, they promised 'redistributive action of the Federal Government' as a way of ensuring the operations of the governments (Fed. Rep. of Nigeria 1976: 13). The origins and continuity of the multistate system is, therefore, grounded on 
intergovernmental transfer payments. A commitment to a no-bailout policy would contradict the fiscal foundations of a multistate federalism such as Nigeria.

Thirdly, Nigeria's fiscal arrangement deliberately aims to avoid asymmetrical federalism. The country's early federal compact was without sensitivity to equality in the size and population of the then regions, an insensitivity that ultimately led to the three-year Biafra secessionist war of 1967-70. Since the 1970s, the country's reinvented multistate federalism has incorporated constitutional rules for minimising deep disparities in the fiscal capacities of the constituent states, disparities that could have made few resource-endowed states economically powerful to the point of dominating the federation. Hence oil and gas revenues are distributed equitably across the country, a distribution that includes the creation of a special ministry for the oil producing region, the establishment of a commission dedicated to providing infrastructure in the region, and the earlier mentioned 13\% derivation. Equitable redistribution makes for near-symmetry in fiscal strength, and also guarantees the social solidarity dimension of federalism, the 'idea that different parts, endowed with different fortunes and resources, are to share in a federal commonwealth' (Hueglin \& Fenna 2006: 51). SGT's arguments would be at odds with a commitment to social solidarity and nation building, given the theory's insistence on subnational fiscal autonomy, minimal transfer payments and a no-bailout policy. Such insistence would require that important taxing jurisdictions, especially oil and gas, be assigned to the states. In fact, in contemporary Nigerian public discourse, there is a loud and sometimes threatening call for political restructuring that entails full fiscal autonomy for the states. In the view of some of the local actors pressuring for devolution, full fiscal autonomy would enable the federating units to develop according to their abilities, make for competition among the units, and enthrone "true federalism". The problem with this position is that full devolution might generate an unusual asymmetrical federalism in which the few oilproducing states possess enormous financial power and potentially act as creditors to the have-not states. Given the volatile ethnic relations in a country such as Nigeria, and the fact that the federation is of an ethno-federal type, the deep dichotomy of extremely rich versus poor constituent units could generate ethnic resentments that may lead to the untimely demise of the federation.

Finally, in a context where all subnational governments are dependent on intergovernmental transfers and are many in number, the central government would not be 
in the position to commit to a policy that minimises transfers or prohibits bailouts. To illustrate, the Nigerian FRA prohibits the states from acquiring loans for recurrent expenditure spending. However, when the subnational economic crisis began in 2015, the Federal Government quickly overlooked its own FRA by providing the cash strapped states with $\$ 2.1$ billion bailout loans to settle their backlog of workers' pay. Even though several states wasted the funds, the centre still came up with another bailout facility in 2016 and a third in 2017. The centre could not stand-by and watch because the jurisdictions are many; too many to fail. "Saying no" to them could trigger their economic collapse and a possible political instability across the country. In turn, this would invite charges of administrative incompetence on the part of the governing party in the centre, charges that could lead to electoral defeat and loss of power. The centre has voters to whom it is accountable. The consequences of 'saying no' to jurisdictions in distress are so severe that government could not sensibly commit to such a destructive policy.

\section{The Problem of Idealising $19^{\text {th }}$ Century American Federalism}

What emerges from the preceding discussion is the difficulty of generalising about federal institutions as SGT does. There is no such thing as ideal federalism, as Riker (1969: 146) noted several decades ago when he wrote that the concept is 'a constitutional legal fiction which can be given whatever content seems appropriate at the moment.' Yet, SGT prescribes what amounts to an ideal fiscal regime. Knowingly or unknowingly, some contemporary Nigeria political actors propagate this inaccurate idea when they advocate so-called "true federalism as found in the United States." Federations differ widely in many dimensions and each reflects the features and public culture of its society (Simeon and Conway 2001). For example, egalitarian Australia has little tolerance for horizontal fiscal inequality while the highly individualist United States is indifferent to such inequality. Canada with its tempered individualism fits in between the two extremes. The arguments of SGT amount to disregarding realities on the ground for some abstract ideals. This runs counter to Riker's (1969: 146) counsel that it is best 'to go behind the fiction' of federalism 'to study the real forces in a political system.' Indeed, the Nigerian experience proved that real forces on ground matter, that they actually give content to the concept of federalism. 
The ideas propagated by SGT turn out to be derived from a particular federation, the United States. In American federalism, equalisation (solidarity) transfers are non-existent and there was a credible federal commitment against bailout from the 1840 s until the $20^{\text {th }}$ century. The theory extracted and glorified these features as models for the rest of the world, very much against Elazar's (1987: 61) observation about the impressive 'variety of federal arrangements .... in the world'. The prescriptions of SGT are of little value, considering that the features it seeks to universalise no longer apply to the American federation from which they were extracted. For example, it is a fact that equalisation payments remain absent, but cooperative transfer programmes have been institutionalised since the New Deal era - a development that gave rise to the concept of cooperative federalism. In spite of the existence of competitive federalism since the 1980s, the number of US federal aid programmes to the states increased from 327 in 1965 to 608 in 1995, such that overall transfer payments accounted for $29.6 \%$ of the states' revenue in the mid1990s. By 2010, the number of federal aid programmes to the states was 1,122 which amounted to an average of $\$ 2,187$ per capita (Edwards 2013: 34 \& 38; Watts 2002: 495). Furthermore, the no-bailout policy has also been eroding since the mid-20th and effectively died following the passage of the 2009 American Recovery and Reinvestment Act. The Act provided $\$ 223$ billion to state governments (Greve 2012: 31), equivalent to 30\% of their revenues for 2009. All American states (except Vermont) are mandated to balance their budgets, but this has been impossible especially since 2008, and states have had to rely on federal transfers to bridge their budgetary gaps (Ter-Minassian and Fedelino (2010).

SGT romanticises features that have disappeared from American federalism. This is reflected in Rodden (2012), Greve (2012; 2011), and Skeel (2011) whose arguments for reviving and bolstering market discipline are rooted in nineteenth century US fiscal policy. Changes in American federalism confirm the well-known idea that federalism is variable. It would, therefore, be a mistake to use a variant at a particular place in the past as a model for others. Like SGT advocates, contemporary Nigerian actors are guilty of this error when they press for "true federalism as practiced in the United States."

\section{Conclusion}


Federal transfers are the very foundation of some federations. This is the case with Nigeria's multistate federalism. It is also true of Canada that has the distinctive character of being a sharing and polite society partly on account of the institutionalisation of transfers since Confederation in 1867 (with equalisation payments formally worked out in 1957). The same is true of culturally egalitarian Australia where transfers were initially designed at the commencement of the federation in 1901 for the political goal of maintaining the integrity of the country. SGT is somewhat blind to cultural and political differences across countries as it seeks to universalise a pre-New Deal rugged and highly aggressive American individualism. As the Nigerian case study data has shown, adopting the theory could bring some federations to their untimely demise. It is not surprising that no federation with a history of transfer payments has abandoned the arrangement, despite claims that the payments make for inefficiencies. The Australian system, highly criticised for being inefficient (Kirchner 2013) has undergone revisions but never abandoned. Admittedly, the case study showed that transfer payments give rise to fiscal indiscipline among public officials, but such a problem would simply mean that governments ought to align their expenditures with their revenues, instead of abandoning the arrangement as the SGT argues for.

\footnotetext{
* Wilfrid Laurier University, Waterloo, Ontario, Canada.

I The centre is assigned with import, export, excise, mining (oil and gas), value added, and company, taxes while the subnational governments are left with property tax (which most of the states do not impose), motor vehicles licenses, land tax, entertainment tax, and market trading licences, among others. The only important revenue source assigned to the subnational governments is personal income tax, excluding tax imposed on personnel in the Foreign Service, military, police, and residents of the Federal Capital Territory (FCT). The tax assignment seems to reflect the ideas of the FGT.

II The low figure for 2015 was partly on account of disruption in supplies by Niger delta militants and the dramatic fall in the international price of oil.

III It should be noted that revenues from value added taxes (VAT) are required by law to be placed in a separate common account, VAT Account, in the Central Bank for sharing among the governments.

IV 'The states' share of $26.72 \%$ is horizontally shared among all the thirty-six on the basis of several factors, namely: equality, population, landmass, terrain, internal revenue generation effort, and social development. The VAT Account is shared in the ratio of $15 \%, 50 \%$, and $35 \%$ to the Federal, State, and Local Governments respectively.

v The most affected were: Kaduna, Kwara, Plateau, Bayelsa, Benue, Borno, Yobe, Imo, Taraba, Kogi, Bauchi, Delta, Oyo, Nassarawa and Ogun states.
}

\section{References}

- $\quad$ Buchanan James M., 1950, 'Federalism and Fiscal Equity', American Economic Review, XL(4): 583-599. 
- $\quad$ Burret Heiko T and Feld Lars P., 2014, 'A Note on Budget Rules and Fiscal Federalism', CESifo DICE Report: Journal for Institutional Comparisons, II(1): 3-11.

- $\quad$ (CBN) Central Bank of Nigeria, 2015, Annual Report 2015, Central Bank of Nigeria, Abuja.

- $\quad(\mathrm{CBN})$ Central Bank of Nigeria, 2014a, Annual Economic Report for 2014, Central Bank of Nigeria, Abuja.

- $\quad$ (CBN) Central Bank of Nigeria, 2014b, Statistical Bulletin: Public Finance Statistics 2014, Central Bank

- $\quad$ of Nigeria, Abuja.

- $\quad$ (CBN) Central Bank of Nigeria, 2013, Annual Economic Report for 2013, Central Bank of Nigeria, Abuja.

- $\quad$ (CBN) Central Bank of Nigeria, 2010, Annual Report and Statement of Account for 2009, Central Bank of

- $\quad$ Nigeria, Abuja.

- Debt Management Office, 2015, 'Total Domestic Debt of the 36 States and the FCT, as at December 31, 2015, Debt Management Office, https://www.dmo.gov.ng/debt-profile/sub-national-debts.

- Debt Management Office, 2013, Annual Report and Statement of Accounts, Debt Management Office, Abuja.

- $\quad$ Edwards Chris, 2013, 'Fiscal Federalism in the United States', in Clemens Jason and Veldhuis Niels (eds), Federalism and Fiscal Transfers: Essays on Australia, Germany, and Switzerland and the United States, Fraser Institute, https://www.fraserinstitute.org/sites/default/files/federalism-and-fiscal-transfers-rev.pdf.

- $\quad$ Eisen Ben and Lammam Charles, 2016, 'Follow the Equalization Money to Central Canada', Financial Post, January 20. http://business.financialpost.com/opinion/follow-the-equalization-money-to-centralcanada.

- $\quad$ Ekeh Peter, 1975, 'Colonialism and the Two Publics in Africa: A Theoretical Statement', Comparative Studies in Society and History, XVII(1): 91-112.

- $\quad$ Elazar Daniel, 1987, Exploring Federalism, The University of Alabama Press, Tuscaloosa (Alabama).

- Federal Republic Nigeria, 2007, Fiscal Responsibility Act 2007, 2007 Act 31, The National Assembly, Abuja, $\quad$ http://www.internationalbudget.org/wp-content/uploads/Nigeria-FiscalResponsibilityAct2007English.pdf.

- $\quad$ Federal Republic of Nigeria, 1976, Federal Military Government Views on the Report of the Panel on Creation of States, Federal Ministry of Information, Lagos.

- Greve Michael, 2012, 'Our Federalism is Not Europe’s. It’s Becoming Argentina's', Duke Journal of Constitutional Law and Public Policy, VII(1): 17-42.

- Greve, Michael, 2011, 'Bailouts or Bankruptcy?', Engage: The Journal of the Federalist Society Practice Groups, XII(2): 107-110.

- Hueglin Thomas O. and Fenna Alan, 2006, Comparative Federalism: A Systematic Inquiry, Broadview Press, Peterborough (Ontario).

- Independent Corrupt Practices \& Other Related Offences Commission, 2016, 'How States Used Bailout Funds', http://icpc.gov.ng/monitoring-bailout-funds/.

- Inman Robert P. and Rubinfeld Daniel L.,1997, 'Rethinking Federalism', Journal of Economic Perspectives, XI(4): 43-64.

- Jonathan Goodluck, 2016, 'How We were Pressured to Squander Excess Crude Saving', Premium Times, June 7. http://www.premiumtimesng.com/news/headlines/204809-pressured-squander-18bn-excesscrude-saving-jonathan.html.

- $\quad$ Kirchner Stephen, 2013, 'Lessons from the Australian Experience', in Clemens Jason and Veldhius Niels (eds), Federalism and Fiscal Transfers: Essays on Australia, Germany, Switzerland, and the United States, Fraser Institute, 17-30, https://www.fraserinstitute.org/sites/default/files/federalism-and-fiscal-transfers-rev.pdf.

- Kornai János et al., 2003, 'Understanding the Soft Budget Constraint', Journal of Economic Literature, XLI(4): 1095-1136.

- $\quad$ Kornai János, 1986, 'The Soft Budget Constraint', Kyklos, XXXIX(1): 3-30.

- Kornai János, 1980, Economics of Shortage, North-Holland Publishers, Amsterdam.

- McKinnon Ronald and Nechyba Thomas, 1997, 'Competition in Federal Systems: The Role of Political and Financial Constraints', in Ferejohn John and Weingast Barry R. (eds), The New Federalism: Can the States be Trusted?, Hoover Institution Press, Stanford, 3 - 61.

- $\quad$ McLure Charles E., 2001, 'The Tax Assignment Problem: Ruminations on How Theory and Practise 
- Depend on History', National Tax Journal, LIV(2): 339-344.

- Mieszkowski Peter \& Musgrave Richard A., 1999, 'Federalism, Grants, and Fiscal Equalization', National Tax Journal, LV(2): 239-260.

- $\quad$ Musgrave Richard Abel, 1959, The Theory of Public Finance, McGraw-Hill, New York.

- National Bureau of Statistics, 2012, Annual Abstract of Statistics, National Bureau of Statistics, Abuja.

- $\quad$ Oates Wallace E., 2005, ‘Toward A Second-Generation Theory of Fiscal Federalism’, International Tax

- $\quad$ and Public Finance, XII(4): 349-373.

- Oates Wallace E., 2004, 'An Essay on Fiscal Federalism', in Baimbridge Mark and Whyman Philip (eds), Fiscal Federalism and European Economic Integration, Routledge, New York, 13-47.

- $\quad$ Oates Wallace E., 1972, Fiscal Federalism, Harcourt, New York.

- Olowu Dele and Wunsch James, 2014, 'Nigeria: Issues of Capacity and Accountability in Decentralization', in Dickovick J. Tyler and Wunsch James S. (eds), Decentralization in Africa: The Paradox of State Strength, Lynne Rienner, Boulder (Colorado), 159-181.

- $\quad$ OPEC, 2015, Annual Statistical Bulletin, Organization of the Petroleum Exporting Countries, Vienna.

- Phillips Adedotun, 1991, 'Managing Fiscal Federalism: Revenue Allocation Issues', Publius: The Journal of Federalism, XXI(4): 103-111.

- $\quad$ Phillips, Adedotun, 1971, 'Nigeria's Federal Financial Experience', The Journal of Modern African Studies, IX(3): 389-408.

- $\quad$ Rodden Jonathan, 2012, 'Market Discipline and U.S. Federalism', in Conti-Brown Peter and Skeel David A. (eds) When States Go Broke: The Origins, Context, and Solutions for the American States in Fiscal Crisis, Cambridge University Press, New York, 123-145.

- $\quad$ Rodden Jonathan et al., 2003, 'Introduction and Overview', in Rodden Jonathan et al. (eds), Fiscal Decentralization and the Challenge of Hard Budget Constraints, MIT Press, Cambridge, 3-31.

- Rodden Jonathan, and Wibbels Erik, 2002, 'Beyond the Fiction of Federalism: Macroeconomic Management in Multitiered Systems', World Politics, LIV(4): 494-431.

- Rosas Guillermo, 2006, 'Bagehot or Bailout? An Analysis of Government Responses to Banking Crises', American Journal of Political Science, L(1): 175-191.

- Schiff Maurice and Valdes Alberto, 1992, The Plundering of Agriculture in Developing Countries, The World Bank, Washington DC.

- Simeon Richard and Conway Daniel-Patrick, 2001, 'Federalism and the Management of Conflict in Multinational Societies', in Gagnon Alain-G and Tully James (eds), Multinational Democracies, Cambridge University Press, Cambridge, 338-365.

- $\quad$ Skeel David A., 2011, 'Give States a Way to Go Bankrupt: It's the Best Option for Avoiding a Massive Federal Bailout', California Journal of Law and Public Policy, III(2): 1-6.

- Ter-Minassian Teresa, 1997, 'Decentralization and Macroeconomic Management', Issue 97-155 IMF Working Paper, International Monetary Fund, Washington, DC.

- Ter-Minassian Teresa and Fedelino Annalisa, 2010, 'Impact of the Global Financial Crisis on SubNational Governments' Finances', Bank of Italy Occasional Paper, Economic Research Department, Rome, Italy. https://papers.ssrn.com/sol3/papers.cfm?abstract id=1985235.

- Tiebout Charles, 1961, 'An Economic Theory of Fiscal Decentralization', in National Bureau Committee for Economic Research (ed), Public Finances: Needs, Sources, and Utilization, Princeton University Press, Princeton, 79-96.

- Watts, Ronald, 2001, 'The Distribution of Powers, Responsibilities, and Resources in Federations', in Griffiths Ann L. and Karl Nerenberg (eds), Handbook of Federal Countries, McGill-Queen's University Press, Montreal \& Kingston: 448-470.

- Weingast, Barry, 2014, 'Second Generation Fiscal Federalism: Political Aspects of Decentralization and Economic Development', World Development, LIII (January): 14-25.

- Weingast Barry, 1995, 'The Economic Role of Political Institutions: Market-Preserving Federalism and Economic Development', Journal of Law, Economics and Organization, XI(1): 1-31.

- Wildasin David, 1997, Externalities and Bailouts: Hard and Soft Budget Constraints in Intergovernmental Fiscal Relations, Volume 1843, The World Bank, Washington (DC).

- World Bank, 2013, Nigeria Economic Report, No 1, May, World Bank, Washington (DC). 
- World Bank, 2007, Nigeria - Lagos State - States Finances Review and Agenda for Action, World Bank, Washington (DC). http://documents.worldbank.org/curated/en/2007/05/7790064/nigeria-lagos-statestates-finances-review-agenda-action.

- World Bank, 1994, Adjustment in Africa. Reforms, Results, and the Road Ahead. Washington, DC: World Bank and Oxford University Press, 